\title{
Therapeutics and Vaccines: Strengthening Our Fight Against the Global Pandemic COVID-19
}

\author{
Arghyadeep Bhattacharjee $^{1} \cdot$ Manish Saha ${ }^{2} \cdot$ Arpita Halder $^{1} \cdot$ Arka Debnath $^{3} \cdot$ Oindrilla Mukherjee $^{1}$
}

Received: 17 May 2020 / Accepted: 25 November 2020 / Published online: 3 January 2021

(c) Springer Science+Business Media, LLC, part of Springer Nature 2021

\begin{abstract}
The newly identified 2019 novel coronavirus (SARS-CoV-2) has become a public health concern globally posing a significant threat to human health and economy and creating an unprecedented crisis in all spheres of the global life. Emergence of new genotypes of SARS-CoV during the last few years has pointed out the limited efficacy of available vaccines and antivirals, constraining the global response to the COVID-19 outburst to largely monitoring/containment. There is high priority for treatment regimes and new potential therapeutic and vaccine strategies. Several candidates have shown promising outcomes in various in vitro and in vivo models. In addition, clinical trials are in progress to test conceivable therapies showing promising outcomes in various in vivo studies. Unfortunately, very little information is available in the scientific scope which offers details to the diverse strategies being targeted to fight the pandemic, particularly with respect to the molecular targets. This review article summarizes and highlights the ongoing advances and approaches that are being carried out across the globe in designing vaccines and novel therapeutics, with particular reference to the previous knowledge gained from other viral infections like with the earlier SARS and MERS-CoV. A detailed knowledge may pave the way to combat this pandemic COVID-19 as well as prevent similar deadly epidemics in future.
\end{abstract}

\section{Introduction}

Coronaviruses ( $\mathrm{CoV}$ ) are positive-stranded RNA viruses that are responsible for a number of respiratory, gastrointestinal and neurological illnesses [1]. Over the past years, the world has witnessed the outbreak of two major pandemics SARSCoV in 2003 and MERS-CoV in 2012. In late 2019, the Wuhan province of China started reporting numerous cases of pneumonia-like severe respiratory illness of unknown cause [2]. Within a short period of time, this emerging viral infection was referred to as "COVID-19" by the World Health Organization (WHO) and the novel beta-coronavirus

Oindrilla Mukherjee

oindrilla.mukherjee@bt.nitdgp.ac.in

1 Department of Biotechnology, National Institute of Technology Durgapur, Mahatma Gandhi Road, A-Zone, Durgapur, West Bengal 713209, India

2 Department of Cardiology, R.G Kar Medical College \& Hospital, 1, Khudiram Bose Sarani, Bidhan Sarani, Shyam Bazar, Kolkata, West Bengal 700004, India

3 Department of Biotechnology, SRM University, Mahatma Gandhi Road, Potheri, SRM Nagar, Kattankulathur, Chennai, Tamil Nadu 603203, India earned the title Severe Respiratory Syndrome Coronavirus-2 (SARS-CoV-2) [3] by the International Committee on Taxonomy of Viruses [4]. At present, the disease has become pandemic as declared by World Health Organization (WHO), affecting nearly 200 countries across the globe. In India alone, a staggering 77, 59,640 people have been infected, with 1, 17,236 deaths (latest on October 22, 2020). Globally, more than 41,869,297 people have been affected resulting in $1,140,555$ deaths [5], in addition to huge secondary losses to the economy worldwide. Interestingly, the virus SARSCoV-2 has a genomic sequence that is closely related to its predecessor Severe Acute Respiratory Syndrome (SARS) virus of 2003. This deadly virus most likely originated in bats and is assumed to have initially been transmitted from an animal reservoir to humans through an amplifying host [6]. It is however, the human-to-human transmission that has resulted in a sustained pandemic spread of this severe human infection. The nCoV-19 has surface glycoproteins by which they attach to human cells especially those that have specific Angiotensin-Converting Enzyme 2 Receptors (Ace2R) predominantly found in humans, dogs, bats, swine, non-human primates etc. [7]. Pangolins have been proposed to be the amplifying host as Pangolin-CoV has been shown to have $91.02 \%$ and $90.55 \%$ sequence similarity 
to SARS-CoV-2 and Bat-CoV RaTG13, respectively [8]. The S1 protein of Pangolin coronavirus is also much more closely related to SARS-CoV-2 than to RaTG13 [9].

Reports from various parts of China indicated that the most prominent COVID-19 cases reports severe-to-moderate pathophysiology [10]. The case fatality rate (CFR), which plays a pivotal role in the pathogenicity of the virus, especially during the course of infection, has been reported to be a higher percentage in the elderly male population with an average case fatality rate of $1-7 \%$. Mexico has reported the highest case fatality rate of $9.95 \%$; followed by Italy (7.93\%), the United Kingdom (4.94\%), France (3.42\%), Russia (1.72\%) and Spain (3.16\%) [5]. A higher proportion of the elderly population, lower general immunity against pathogens, as well as life style problems have been suggested to be responsible for this huge mortality in these countries. Patients with comorbidities including hypertension, cardiac problems (heart injury) and diabetes mellitus have been reported to be at a significantly higher risk for COVID-19 infection. The general characteristics and infection mechanism of the virus is described in the next section.

\section{General Features \& Basic Virology of SARS-CoV-2}

Coronaviruses are widespread among humans and other vertebrates and are considered to be the major cause of various neurological and respiratory disorders. SARS-CoV-2 belongs to the Coronaviridae family [11] and are termed as Coronaviruses, because of the presence of their characteristic crownlike appearance made of surface glycoproteins. Mammals are reported to be infected by Alpha- and Betacoronaviruses, whereas Gamma \& Delta variants of the virus typically infect avian species. Coronaviruses consists of a $30 \mathrm{~kb}+$ single stranded positive RNA genome that encodes a number of open reading frames. One frame encodes the spike (S) protein which helps the virus to attach to cell surface receptors followed by its uptake into the endosomes where the $S$ protein is further cleaved by furin like proteases found in many coronaviruses. The other major frame of the genome codes for structural and accessory proteins. The 5' cap structure and 3' poly (A) tail plays an important role in the expression of the replicase that constitutes nearly two third of its genome [12]. A number of non-structural proteins are also present which are generated by processing of different viral protease encoded within the replicase.

SARS-CoV-2 appears to be much more transmissible [13], despite the fact that it shares nearly $79 \%$ genome with the formerly known SARS-CoV. Chemosensory (smell and taste) and gustatory dysfunctions are found to have been strongly affected in COVID-19 patients and is emerging as one of the pivotal interpreters of COVID-19 infection [10].
The surface glycoproteins of the SARS-CoV-2 mainly bind to the cell via the angiotensin-converting enzyme 2 (ACE2) receptors on the alveolar epithelial cells [14], thus infecting the lower airways. The innate immune cells use the Pathogen Recognition Receptors (PRR) to recognise these viral antigens and activate immune signalling pathways [15] to produce various chemokines leading to activation of adaptive immune system. Progression of the infection has also been shown to lead to "Cytokine Storm" and is reviewed in detail later. Many accessory proteins that may contribute to the pathogenicity of the virus have not yet been characterized. ACE2 receptors are not only present in humans but also found in dogs, bats, swine as well as in non-human primates which both explains the animal origin as well as raises questions on the infectivity of this virus in a non-human host as well. The first human to cat transmission was reported from Belgium after a cat was found to be infected with SARSCoV-2 from its owner as reported on March 27, 2020 [16]. Interestingly, the feline ACE2 protein is the homologue of human ACE2, which is the major cellular receptor used by the virus for entering into the cell [16]. The Bronx Zoo authorities have also confirmed that 4 tigers and 3 lions had been tested positive for this novel coronavirus on April 5, 2020 [17].

The current global focus is the development of diverse treatment regimes keeping in minds both short term treatment goals as well as long term sustainable immunity development prospects. This includes the development of novel therapeutics and antiviral drugs, use of cytokines and antibody as well long term sustainable vaccine development against the challenge. The following sections of the review look at each of them individually.

\section{Antivirals and Novel Therapeutics}

Development and search of novel therapeutic agents to control this infection is an absolute need of the hour. The compounds that bind to the virus as well as specific inhibitors inhibiting fundamental processes such as replication $\&$ transcription as well as host cell protease and host cell endocytosis inhibitors need to be evaluated as possible therapeutics [18]. This includes both searches for novel drugs and their targets as well as repurposing of FDA approved drugs. The latter is slightly advantageous as clinical trials will be easier to conduct given that such drugs have already been proved safe for human usage. Clinical trials with a single addition of Ivermectin, an FDA approved anti-parasitic drug to Vero-hSLAM cells $2 \mathrm{~h}$ post infection have shown promising broad-spectrum antiviral activity against SARSCoV-2 in vitro with nearly 5000 fold reduction in viral RNA at $48 \mathrm{~h}$ [19]. A common nucleoside analogue, Remdesivir works against coronaviruses that are closely related to 
SARS-CoV-2 in animal models and also against MERS in non-human primates leading to termination of RNA synthesis and incorporation of mutagenesis [20]. Combination therapy of Remdesivir and Chloroquine has also been found to be effective against a clinical isolate of SARS-CoV-2 in vitro [21]. In another clinical trial Favipiravir, a drug that targets the RNA-dependent RNA Polymerase (RdRP) has been shown to be more effective than Arbidol with a reduction of fever, cough, and other adverse effects within 7 days [22]. Retroviral drugs have also been very promising against coronavirus infections. The combination of protease inhibitors Lopinavir and Ritonavir was used as a treatment for SARS-CoV and had shown promising results [23]. Ritonavir plays an important role in accelerating the half-life of Lopinavir by inhibiting the cytochrome P450 [24]. Scientists are also hopeful about the possible efficacy of Arbidol, a fusion inhibitor [25], as well as ASC09F (HIV protease inhibitor), Darunavir, and Cobicistat.

One of the most striking features of SARS-CoV-2 is that its RNA-dependent RNA polymerase (RdRp) sequence has a $96 \%$ identity to that of SARS-CoV, leading to widespread assumption that drugs developed for SARS-CoV RdRp may show similar efficacy for SARS-CoV-2 [26]. The anti-malarial drug Hydroxychloroquine, along with its anti-inflammatory function has been shown to inhibit SARS$\mathrm{CoV}-2$ infection in vitro. Though hydroxychloroquine is less toxic than Chloroquine, yet a high dose of it may lead to poisoning [27]. Researchers of Qingdao University of China have reported the efficacy of a phosphate derivative of Chloroquine against COVID-19 associated pneumonia in some clinical trials [28]. A clinical trial of Hydroxychloroquine in combination with Azithromycin has also been found to be effective in some cases [29].

As mentioned earlier, ACE2-R is the main target for the virus. This binding has also been shown to affect the balance of renin-angiotensin system leading to pneumonia and other chronic respiratory disorders. Therefore, Angiotensin-Converting Enzyme I (ACE-I) and Angiotensin type-1 receptor (AT1R) inhibitors might be able to reduce pulmonary inflammatory responses and is being currently explored as a possible intervention [30]. Implementation of combination therapy can also be an interesting option for the development of appropriate preventing and control strategies. Lopinavir and Ritonavir, in combination with Ribavirin have earlier shown promising therapeutic efficiency and clinical response among SARS infected patients and thus merits randomized placebo controlled trial among patients infected with SARSCoV-2 [23]. At present, hospitals and health care centres of China are also using neuraminidase inhibitors [18].

In addition to antivirals, other possible therapy includes the use of siRNA, anti-sense RNA and ribozyme, peptide targeting S2, as well as natural products [31]. Scientists have cloned, tagged, and expressed a number of proteins in human cells and identified SARS-CoV-2-human protein-protein interactions that may act as effective molecular targets for antiviral drugs [32]. A bottleneck in this understanding and further commercialization is the lack of interest among the pharmaceutical companies owing to less availability of approved commercially available vaccines and therapeutic agents against $\mathrm{CoV}-2$. PAC-MAN has emerged as an important CRISPR-Cas13 based strategy for the inhibition and degradation of viral RNA. It has been found that CRISPR RNAs targets $90 \%$ of all coronaviruses by cleaving their respective target sequences [33]. Scientists have already analysed therapeutic targets for SARS-CoV-2 and screened and identified potential drugs by computational approach [34]. In a study, important targets such as 3-chymotrypsin-like protease (3CLpro), Spike, RNA-dependent RNA polymerase (RdRp), and Papain-like protease (PLpro) were validated which will provide new insights to treat SARS-CoV infections [34].

Over the past decades, Natural products and their derivatives gained considerable importance as a major source of therapeutics. The source of some of the natural products and flavonoid compounds along with their respective targets [34] has been tabulated (Table 1) which may pave the way for future drug discovery. It must be stressed though, that the use of alternative and complementary medicines like Homoeopathy, Ayurveda against COVID-19 remains obscure and requires extensive investigation.

\section{Cytokine Storm in COVID-19-Therapeutic Intervention}

The membrane fusion and cytoplasmic entry of SARS$\mathrm{CoV}-2$ is highly dependent on the priming reaction of $\mathrm{S}$ protein triggered by the serine protease TMPRSS2 [41]. Pulmonary type-II pneumocytes are included in the cellular entry which provokes an initial immune response with the production of inflammatory cytokines accompanied by a weak interferon (IFN- $\lambda$ ) response [42]. This response is followed by the chemotactic infiltration of monocyte-derived macrophages and neutrophils into the lung tissue, often resulting in a cytokine storm which is characterised by organ damage and massive immune cell infiltration [42]. A thorough understanding of the cytokine storm during the progression of COVID-19, as well as mechanisms to block infiltration and inflammation, will thus prove to be highly critical for patient treatment and controlling mortality rates [43]. Since Interleukin -6 (IL-6) has been shown to play a very important role; a possible therapeutic intervention might be obtained if the signal transduction pathway of IL-6 could be blocked [44]. Tocilizumab is an IL-6R blocker that is capable of blocking the IL-6 signal transduction pathway; hence this monoclonal 
Table 1 List of natural compounds and their targets against SARS-CoV-2

\begin{tabular}{|c|c|c|c|}
\hline Targets & Functions & Natural products & Source \\
\hline Papain-like protease & $\begin{array}{l}\text { Prevents RNA synthesis and replication } \\
\text { [35] }\end{array}$ & $\begin{array}{l}\text { Platycodin } \\
\text { Baicalin }\end{array}$ & $\begin{array}{l}\text { Platycon glandiflorus } \\
\text { Scutellaria baicalensis }\end{array}$ \\
\hline 3C-like main protease (3CLpro) & $\begin{array}{l}\text { Plays an important role in maturation of } \\
\text { Nsps (Non-structural proteins) which is } \\
\text { a requisite for the life cycle of corona } \\
\text { virus [36] }\end{array}$ & $\left.\begin{array}{l}\text { Betulonal } \\
\text { Isodecortinol } \\
\text { Cerevisterol }\end{array}\right]$ & Scutellaria baicalensis \\
\hline RNA-dependent RNA Polymerase (RdRp) & $\begin{array}{l}\text { The conserved protein Nsp12 is an RdRp, } \\
\text { which is the vital enzyme for replication- } \\
\text { transcription machinery of corona virus } \\
\text { [37] }\end{array}$ & $\begin{array}{l}\text { Betulonal } \\
\text { Gnidicin } \\
\text { Gniditrin } \\
\text { 3,3'-di- } O \text {-gallate }\end{array}$ & $\begin{array}{l}\text { Cassine xylocarpa } \\
\text { Gnidia lamprantha } \\
\text { Camellia sinensis }\end{array}$ \\
\hline Helicase & $\begin{array}{l}\text { Nsp13 unwinds DNA and RNA along the } \\
5^{\prime}-3^{\prime} \text { direction and requires NTP [38] }\end{array}$ & $\left.\begin{array}{l}\text { Phyllaemblicin-B } \\
\text { Phyllaemblinol }\end{array}\right\}$ & Seratia genus \\
\hline Inhibition of viral structural proteins & $\begin{array}{l}\text { Targeting Spike proteins and various recep- } \\
\text { tors that are present on the host [39] }\end{array}$ & $\begin{array}{l}\text { Licoflavonol } \\
\text { Cosmosiin } \\
\text { Neohesperidin }\end{array}$ & $\begin{array}{l}\text { Glycyrrhiza uralensis } \\
\text { Scutellaria baicalensis } \\
\text { Citrus aurantium }\end{array}$ \\
\hline Inhibition of virulence factors & $\begin{array}{l}\text { Nsp1, Nsp3c and ORF7a are the three } \\
\text { important virulence factors that affects } \\
\text { host's innate immunity by causing } \\
\text { mRNA degradation, Inhibition of type I } \\
\text { interferon production and resisting host } \\
\text { innate immunity, respectively [40] }\end{array}$ & $\begin{array}{l}\text { Piperacillin } \\
\text { Cefpiramide } \\
\text { lymecycline } \\
\text { Wogonoside } \\
\text { Vitexin }\end{array}$ & $\begin{array}{l}\text { Platycodon grandifloras } \\
\text { Scutellaria baicalensis } \\
\text { Vitex negundo }\end{array}$ \\
\hline $\begin{array}{l}\text { Inhibition or blocking of host specific } \\
\text { receptors and enzymes }\end{array}$ & $\begin{array}{l}\text { ACE2 is the specific receptor of Spike } \\
\text { RBD of SARS-CoV-2 and blocking this } \\
\text { receptor will inhibit entry of virus into } \\
\text { host cells [14] }\end{array}$ & $\left.\begin{array}{l}\text { Phyllaemblicinn G7 } \\
\text { Neohesperidin } \\
\text { Hesperidin }\end{array}\right\}$ & $\begin{array}{l}\text { Phyllanthus emblica } \\
\text { Citrus aurantium }\end{array}$ \\
\hline
\end{tabular}

antibody (MAb) is being tried as a possible drug for treating critical COVID-19 patients [45]. Similarly, Ruxolitinib (a JAK1/JAK2 inhibitor) has been shown to mitigate the cytokine storm in COVID-19 patients [46]. A human antiInterleukin-6 receptor called TZLS-501 may help in preventing lung damage $\&$ chronic inflammation by reducing the amount of IL-6 during cytokine storm and organ infiltration in COVID-19 patients [47]. Dexamethasone has shown promise as an effective treatment in severe cases of COVID-19 that was caused owing to cytokine storm [48]. A neutralising antibody TJM2 produced by I-MabBiopharma may act as an effective treatment against the "Cytokine Storm" [49], as this antibody has been shown to work by targeting the Granulocyte Macrophage Colony Stimulating Factor that is responsible for chronic and acute inflammation [49]. Other specific modulators such as IL-1 receptor antagonists (Anakinra, Siltuximab), Janus kinase inhibitors (Baricitinib, Ruxolitinib), anti-Tumour Necrosis factor- $\alpha$ (TNF- $\alpha$ ) (Adalimumab) etc., may also prove to be promising candidates [43].

\section{Interferon Therapy Against Coronavirus Infections}

The interferons (IFNs) are a group of secreted cytokines that elicit distinct antiviral effects. In particular, IFN- $\alpha$ and $\beta$ are induced in response to viral infections. These act through a common heterodimeric receptor to activate transcription of a diverse set of genes, referred to IFNinducible genes or IFN-stimulated genes, whose protein products are mostly either directly/indirectly antiviral 
in nature. These cytokines have also been reported to modulate the immune system by activating effector cell function, in addition to promoting the development of the acquired immune system [50].

Not surprisingly, Interferon therapy is being widely used for many viral diseases. Many of the IFN drugs are usually injectable, and companies now often produce them in combination with other molecules that leads to increase their life-span in blood. Cuban recombinant human Interferon alfa-2B has been proven effective against various viral infections [51]. The combination of lopinavir-ritonavir and Interferon- $1 \beta$ has been evaluated for MERS in the "MIRACLE" trial [52]. Interferon- $\beta$ has been previously reported to reduce viral loads through improvement in pulmonary function, although it does not reduce viral replication and severe lung pathology against MERS-CoV infections [53]. In vitro inhibition in the growth of HIV has been observed through synergistic action of IFN- $\alpha$ and Azidothymidine [54]. IFN- $\alpha$ has also emerged as a convenient treatment for patients with papillomavirus warts of the larynx and skin (common warts) [54]. Pre-treatment with a single dose of mDEF201 intranasally has been shown to confer protection against SARS-CoV infections in mice [55]. Interestingly a combination of Interferon alfa-2B and Ribavirin has also played a pivotal role in the inhibition of Beta-coronavirus replication in vitro [56]. In line with other works, Lokugamage et al. have shown that SARS$\mathrm{CoV}-2$ is highly sensitive to interferon pre-treatment [57]. However, interferon administration can be lethal if their administration is not properly controlled. In a study by Channappanavar et al., it has been reported that delayed IFN-I signalling leads to tremendous accumulation of highly pathogenic inflammatory monocyte macrophages which can lead to elevation of cytokines and chemokines in the lungs accompanied by impaired virus specific $\mathrm{T}$ cell responses [58]. Interferon therapy thus might emerge as a promising choice in combating the SARS-CoV-2 infections; although identification of its target and its role in immunomodulation requires further investigation.

\section{Antibodies and Passive Immunization}

Passive Immunization is defined as the transfer of antibodies to another individual who is at a risk of infection for the treatment of a disease. Direct or indirect administration of mAbs may help in combating against this pandemic. Previously, human monoclonal antibodies have been developed targeting the HR1 and HR2 domain of the spike protein as well as other viral proteins of SARS-CoV [59]. Leronlimab, a humanized monoclonal antibody specific to the chemokine receptor CCR5 that mitigates cytokine storm is currently under evaluation in a small number of patients experiencing respiratory complications owing to SARS-CoV-2 [60]. The therapeutic and clinical efficiency of Sarilumab, another IL-6 inhibiting monoclonal antibody is also under investigation [61]. Recently, a novel SARS-CoV specific monoclonal antibody CR3022 has been identified which binds to the receptor binding domain of SARS-CoV-2 and is emerging as a promising candidate for the treatment of COVD-19, as a whole or in combination with neutralizing antibodies [62]. In case of MERS infections, mAbs that bound with the epitopes of receptor binding, membrane fusion, and sialic acid binding sites of MERS S protein such as MERS-4, MERS-27, LCA-60, CDC2-C2 had emerged as a possible therapeutic intervention [63]. The mAbs that are specific to the receptor binding domain of SARS-CoV has a cross neutralizing capacity that will enable researchers to evaluate its efficacy against SARS-CoV-2. With the recent advancement in technology, human chain antibodies and humanized nanobodies against SARS-CoV-2 is a possibility; much like the ones used against pathogenic viral diseases such as Dengue, Ebola etc. An advantage of these nanobodies is that they can traverse across the biological membrane and interfere with the viral replication proteins resulting in inhibition of viral replication [64].

Serum therapy and use of plasma (Convalescent Plasma therapy) are also currently evolving to counteract attacks of SARS-CoV-2 and other pathogenic epidemics as clinical trials are currently being carried out in China against this emerging infection [65]. China has reported the efficacy of Convalescent Plasma therapy in improving the clinical circumstances of the severe COVID-19 patients through its clinical benefit, optimal dose, and its time of intervention requires further investigation in larger well-controlled trials [66]. The United States, Italy, India (in most of the states of the country, as approved by the Indian Council of Medical Research) have also started exploring convalescent plasma therapy against COVID-19.

\section{Comorbidity Treatment Regimes for COVID-19 Patients}

Numerous evidences from the global pandemic have clearly pointed out that individuals with pre-existing comorbidities are significantly at a much higher risk of dying from COVID-19 [67]. Thus it is necessary to explore the biological mechanisms that lead to this risk for the development of appropriate therapies and repurposed treatments.

\section{Hypertension}

Patients suffering from hypertension are currently at the highest risk of severe infection and mortality. ACE inhibitors (ACI) and Angiotensin receptor blockers (ARB) are used to 
treat COVID-19 patients suffering from hypertension [68]. Studies have also revealed that those patients who were treated with non-ACI/ARB suffered from other additional comorbidities [69].

\section{Cardiovascular Disorders}

Severe cardiovascular complications such as myocarditis, acute coronary syndrome, cardiogenic shock, heart failure as well as coagulation abnormalities are shown to develop in COVID-19 patients [70]. Coagulation abnormalities are characterised by elevated levels of prothrombin, fibrinogen, D-dimer, C-reactive protein (CRP), etc. [71]. Normally patients with cardiac problems are treated with angiotensin-converting enzyme inhibitors and angiotensin receptor blockers. Besides calcium channel blockers are also used [72]. However, in case of heart attack, $\beta$-blocker, Diuretics, ARNI (Angiotensin receptor-neprilysin inhibitors) are generally used [73]. Antiplatelets, $\beta$-blockers, ACE inhibitors, and Nitrate group of drugs are used for COVID induced acute myocardial infarction [72]. Although there are some evidence of COVID-19 to be considered as a blood clotting disorder, yet the role of blood thinners in the prevention and treatment of blood clots in COVID-19 requires further investigations [74].

\section{Diabetes Mellitus}

Type 2 diabetes is clinically featured by chronic inflammation and severe impairment in metabolism. Chronic inflammation in diabetic patients makes them much more susceptible to hyper-inflammation and cytokine storm [75]. Normally diabetic patients are treated with regular medications such as DPP4 inhibitors, Alpha glucoside inhibitors, SGLT2 inhibitors, Sulfonylureas, Metformins etc. In patients with moderate to severe COVID symptoms, insulin is being administered, while oral medications are being stopped. If the oxygen saturation falls below 95\%; steroids like Dexamethasone are being used [76].

\section{Kidney Disorders}

Patients with kidney disorders have been recommended not to stop their ACE inhibitors or ARBs to prevent sudden heart attack or other impairment in kidney function. Immunosuppressants are given to those undergoing kidney transplantation and suffering from COVID-19 [77]. Nephrologists recommend acetaminophen for pain relief and fever. Patients with chronic kidney disorders are usually advised to continue with their treatment of $\mathrm{Ca}^{2+}$ metabolism drugs and Vitamin D, even on being infected with the virus. On the other hand, hemodialysis is a common treatment for acute kidney disorders or kidney failure and is also advised to be continued [78].

\section{Liver Diseases}

COVID-19 patients with significant liver damage or liver injury are being treated with regular hepatoprotective, anti-inflammatory, and jaundice reducing agents such as polyenephosphatidylcholine, glycyrrhizic acid, and vitamin E [79], depending upon the liver function injury and its associated symptoms. This is to be noted that Glycyrrhizin which was a preferred anti-inflammatory drug against acute liver damage has been found to have strong antiviral activity against SARS-CoV-2 [80].

\section{Respiratory Disorders}

COPD (Chronic obstructive pulmonary disease) patients are very much susceptible to severe pneumonia upon infection with SARS-CoV-2 owing to enhanced expression of ACE2 receptor in the respiratory airways. The common respiratory medications given to COPD patients include inhaled and systemic corticosteroids, long-acting $\beta_{2}$-agonists, and muscarinic antagonists [81]. But whether these medications mitigates or exacerbates COVID-19 infections remains obscure till date. Previously it has been found that the use of corticosteroids has resulted in increased mortality and delayed viral clearance against MERS [82]. However, a controlled trial of Dexamethasone ("RECOVERY" trial) conducted in the United Kingdom showed a one-third reduction in mortality [83]. Bronchodilators are frequently administered via nebuliser in hospitalised patients with severe symptoms of COVID-19 [84]. Critical patients having hypoxemic COPD and COVID-19 are given controlled oxygen therapy as the first line treatment.

\section{Beta Coronavirus Vaccine Design: A Retroprospective Overview}

Although there is extensive research on the previous SARS$\mathrm{CoV}$ and MERS-CoV, yet there are neither licensed neither vaccines nor therapeutics to combat these infections. Thus it is of utmost importance to develop vaccines or post-exposure prophylaxis not only for the current pandemic but also for the prevention of future epidemics.

Information collected from past studies on SARS-CoV and the related MERS-CoV vaccine efforts have highlighted the fact that the spike glycoprotein is an ideal target for vaccine design. Recent studies on determining the structure of SARS-CoV-2 receptor binding domain (RBD) have shown that although ACE2 is the major cell receptor in both SARSCoV-2 \& SARS-CoV, the spike protein of the former binds 


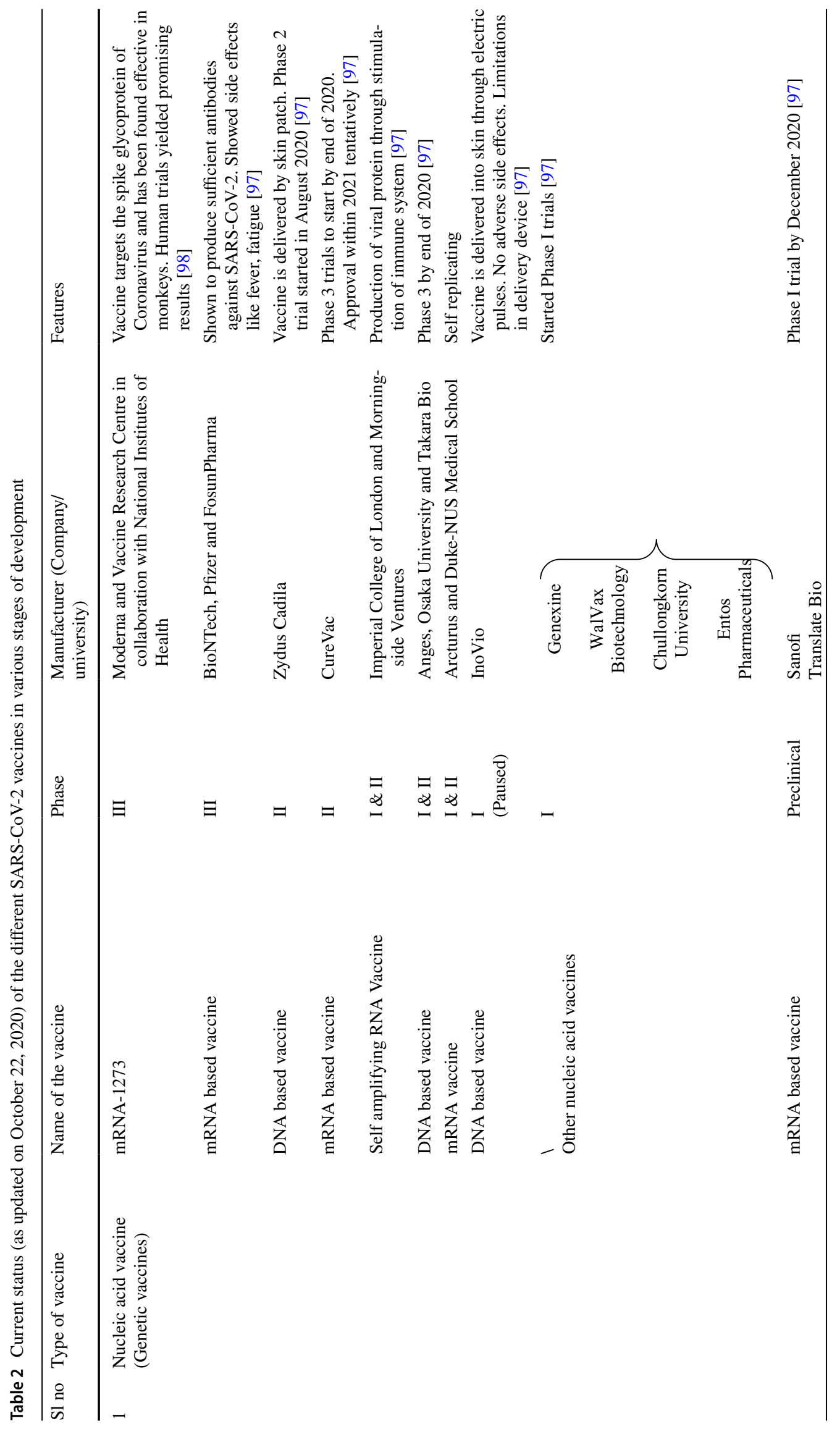




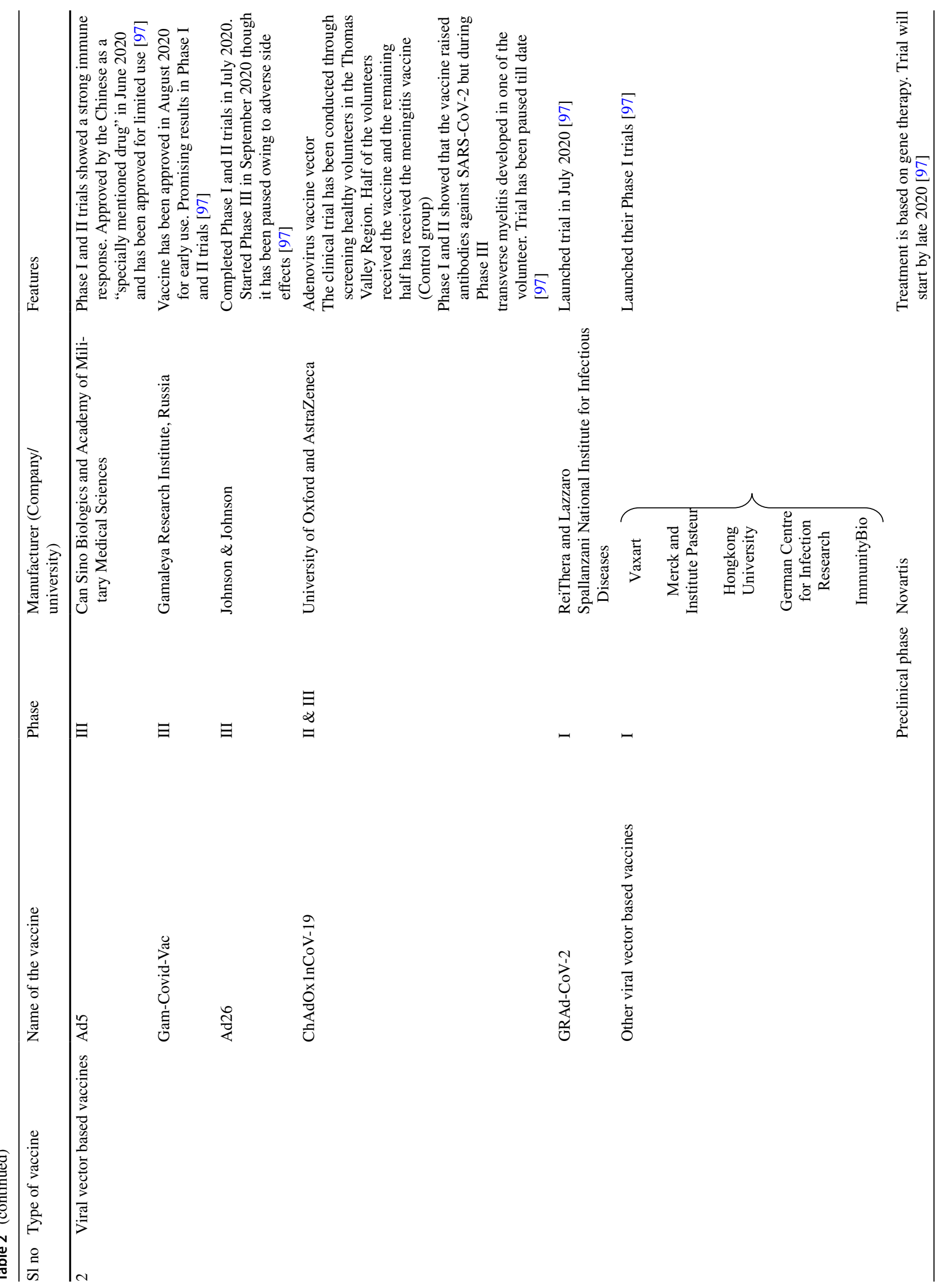




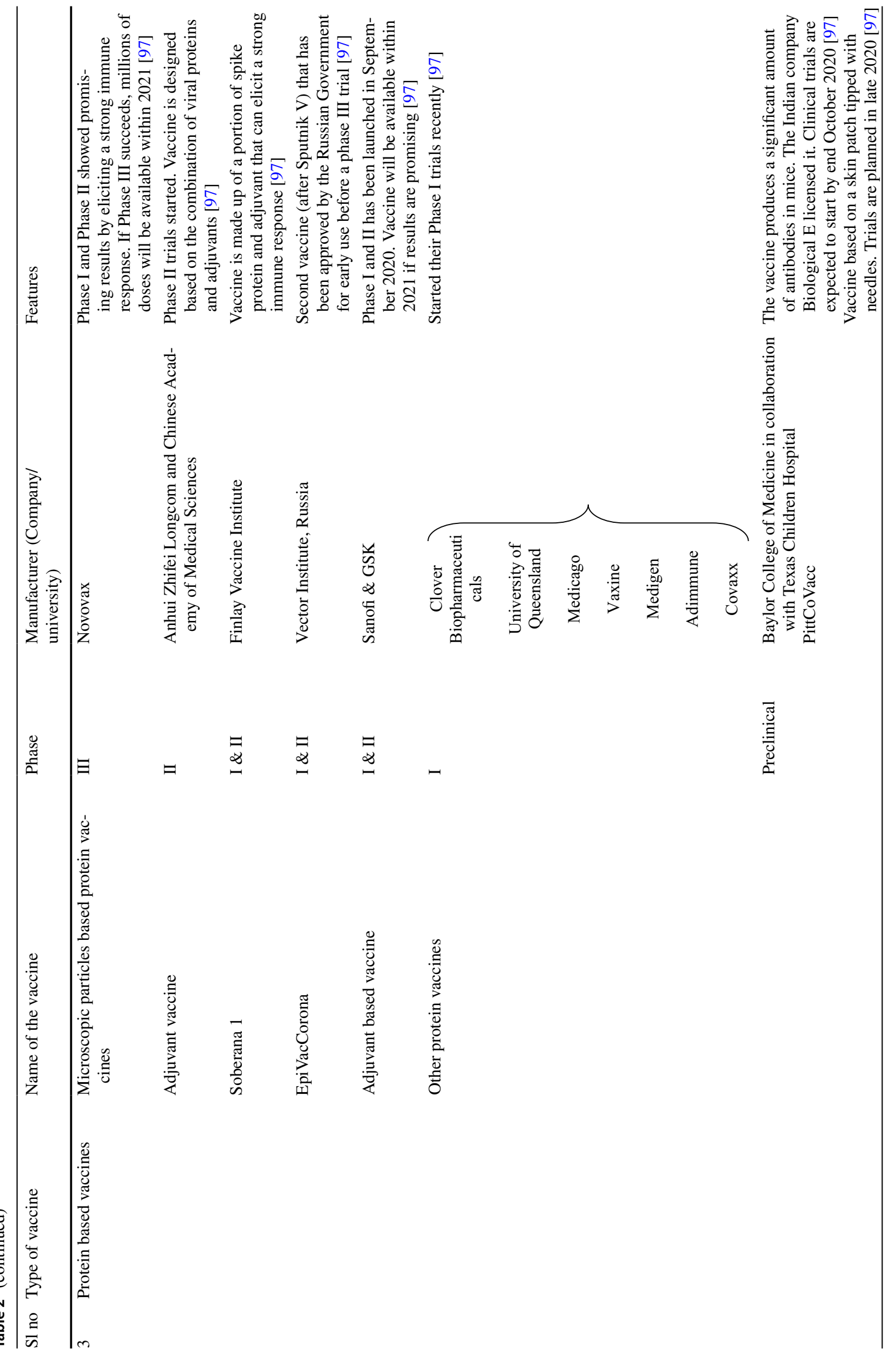




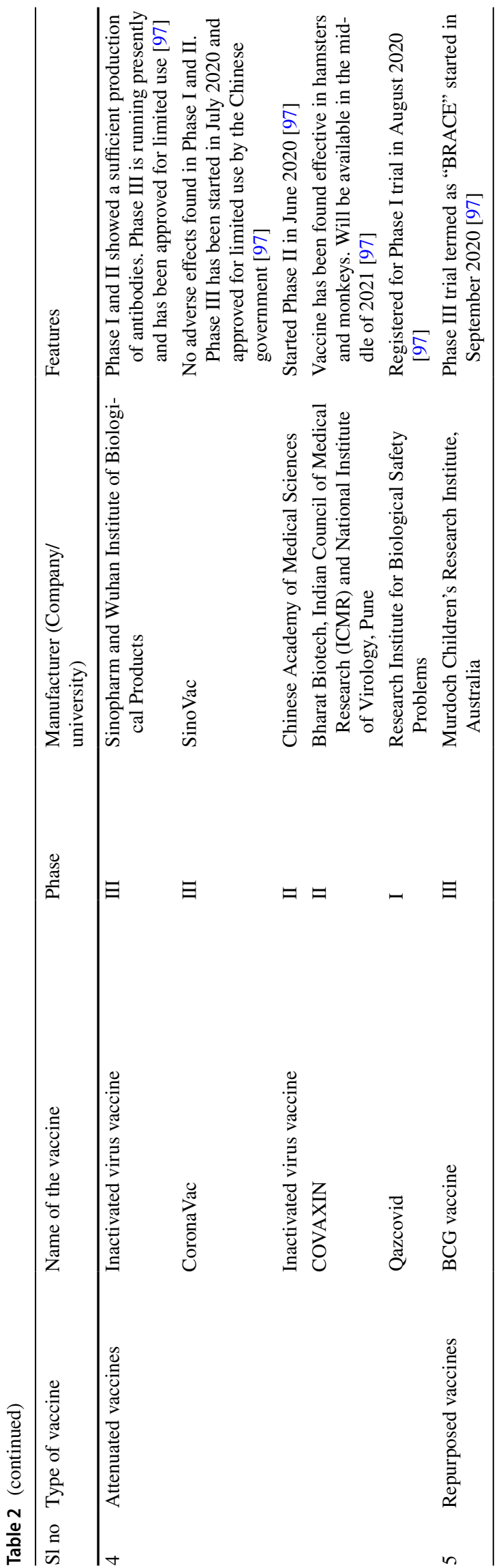

approximately 10 times more tightly than the latter [85]. The antisera induced by the receptor binding domain of SARS-CoV exhibits cross neutralization with the SARS$\mathrm{CoV}-2$ and thus may emerge as potential candidates for developing vaccines against both the infections. However, a problem in the vaccination strategy of SARS emerged the fact that although proven safe and immunogenic, the animals undergoing vaccination had shown significant disease as well as clinical symptoms upon challenge. For example, severe complications like lung damage and infiltration of the eosinophils in mice were reported, despite vaccination with live viral strains [86]. Although vaccination against SARS-CoV and MERS-CoV is associated with enhanced survival, reduction in virus titers, and/or less morbidity as compared to unvaccinated animals in animal models [87], an ideal vaccine developed for SARS-CoV-2 should preferably be less toxic, safer, and requiring less dosage. Scientists have identified a potent fusion inhibitor targeting the HR1 \& HR2 domain of spike glycoprotein that could be used for treatment and prevention against SARS-CoV-2 and other SARSCoVs [88]. Previously, antiviral lipopeptides having in-vitro fusion inhibition capacity have been genetically engineered as a prophylaxis treatment against the Nipah virus [89]. During the outbreak of SARS virus, Subunit vaccines have also been found to generate a strong and robust immune response against the spike protein that prevents it to dock with the host ACE2 receptor through induction of neutralizing antibodies [90]. Viral vectors like Rabies virus can also be a suitable option as it produces significantly higher levels of antibody response and cellular immunity [91]. Immunoinformatics and Molecular dynamics simulation studies revealed that the Cytotoxic T lymphocytes (CTL) epitopes and spike protein epitopic region interacts with MHC-I and MHC-II peptides and these epitopes can act as excellent targets for the design of effective vaccines against SARS-CoV-2 [92]. These targets might be helpful in designing a cost competitive, safe, less toxic vaccine with high therapeutic efficiency in humans against the virus.

\section{Recent Advancement in Vaccine Development Around the Globe}

Vaccination has made one of the greatest contributions in human health through the successful eradication of the Small Pox and the near eradication of Polio. The current outbreak of COVID-19 highlights a significant ongoing need for the rapid design, production, and testing of candidate vaccines. This crisis has accelerated the development of novel coronavirus vaccines by multiple pharmaceutical companies and research organisations. For example, The Canadian Institute for Health Research (CIHR) is funding Medico for developing drug candidates and antibodies against SARS-CoV-2 
in collaboration with the Disease Research Centre of Laval University [93]. Scientists have already shown that avian infectious bronchitis (IB) vaccine strain $\mathrm{H}$, may be beneficial in people suffering from SARS infection [94]. Taking this idea into consideration, the Infectious Bronchitis Virus (IBV) has been modified genetically by the MIGAL Research Institute in Israel and will hopefully be available in oral forms soon. Kim and his colleagues have established a microneedle array based recombinant vaccination strategy which is capable of inducing virus specific potent antibody responses against SARS \& other emerging infectious pathogens [95]. The Texas Children Hospital Centre for Vaccine development, in collaboration with the University of Texas and New York Blood Centre, has developed a subunit vaccine that has shown to have a higher protective immunity on viral challenge when formulated on alum [96]. The Italian Company Takis has developed an RNA vaccine against the gene that codes for the spike protein of SARS-CoV-2 and is expected to start its human trial shortly [97].

The status of the different vaccines currently under development and/or trial has been summarized in Table 2.

\section{Conclusions}

Researchers around the world are racing for effective and suitable vaccine candidates and novel therapeutics for controlling the deadly COVID-19. Typically, the clinical development of a vaccine proceeds with small phase I trials for safety evaluation through formal toxicology testing in humans, followed by phase II trials through dosage formulation and phase III trials, in which the efficacy and safety of a vaccine are evaluated in a larger group. All of the therapeutics and vaccines also must be tested in an appropriate animal model before human trials. However, in this case, it has to be noted that the virus does not grow and infect wild-type mice, which has been shown to exhibit only mild clinical symptoms [86]. Despite all the odds, consolidated efforts on research are the only way forward as the world awaits successful trials of therapies and vaccines to fight this pandemic and prepare for the next ones.

Acknowledgements The authors express their deep gratitude to the Science \& Engineering Research Board (SERB) Government of India for the financial assistance to AB (Grant no. SRG/2019/000457).We are also thankful to RG Kar Medical College \& Hospital for providing us with useful insights and constant support throughout.

Author Contributions AB: Manuscript preparation, Idea development, and Manuscript revision; MS: Consultancy; AH: Manuscript preparation and Manuscript revision; AD: Manuscript preparation: OM: Idea development, Manuscript preparation, and Manuscript revision.

\section{Compliance with Ethical Standards}

Conflict of interest The authors declare that they have no competing interests.

\section{References}

1. Kissler SM, Tedijanto C, Goldstein E, Grad YH, Lipsitch M (2020) Projecting the transmission dynamics of SARS-CoV-2 through the postpandemic period. Science 368:860

2. Andersen KG, Rambaut A, Lipkin WI, Holmes EC, Garry RF (2020) The proximal origin of SARS-CoV-2. Nat Med 26(4):450-452

3. Wu F, Zhao S, Yu B, Chen YM, Wang W, Song ZG, Yuan ML (2020) A new coronavirus associated with human respiratory disease in China. Nature 579(7798):265-269

4. Gorbalenya AE (2020) Severe acute respiratory syndrome related coronavirus: the species and its viruses, a statement of the Coronavirus Study Group. BioRxiv

5. Worldometer (2020) COVID-19 coronavirus pandemic. Worldometer. https://www.worldometers.info/coronavirus/. Accessed 22 Oct 2020

6. Zhou P, Yang XL, Wang XG, Hu B, Zhang L, Zhang W, Chen HD (2020) A pneumonia outbreak associated with a new coronavirus of probable bat origin. Nature 579(7798):270-273

7. Letko M, Marzi A, Munster V (2020) Functional assessment of cell entry and receptor usage for SARS-CoV-2 and other lineage B betacoronaviruses. Nat Microbiol 5(4):562-569

8. Lam TTY, Shum MHH, Zhu HC, Tong YG, Ni XB, Liao YS, Leung M (2020) Identification of 2019-nCoV related coronaviruses in Malayan pangolins in southern China. BioRxiv

9. Zhang Z, Wu Q, Zhang T (2020) Pangolin homology associated with 2019-nCoV. BioRxiv

10. Huang C, Wang Y, Li X, Ren L, Zhao J, Hu Y, Cheng Z (2020) Clinical features of patients infected with 2019 novel coronavirus in Wuhan, China. Lancet 395(10223):497-506

11. Channappanavar R, Zhao J, Perlman S (2014) T cell-mediated immune response to respiratory coronaviruses. Immunol Res 59(1-3):118-128

12. Coutard B, Valle C, de Lamballerie X, Canard B, Seidah NG, Decroly E (2020) The spike glycoprotein of the new coronavirus 2019-nCoV contains a furin-like cleavage site absent in CoV of the same clade. Antiviral Res 176:104742

13. de Wit E, van Doremalen N, Falzarano D, Munster VJ (2016) SARS and MERS: recent insights into emerging coronaviruses. Nat Rev Microbiol 14(8):523

14. Wan Y, Shang J, Graham R, Baric RS, Li F (2020) Receptor recognition by the novel coronavirus from Wuhan: an analysis based on decade-long structural studies of SARS coronavirus. J Virol 94(7):10. https://doi.org/10.1128/JVI.00127-20

15. Khan S, Siddique R, Shereen MA, Ali A, Liu J, Bai Q, Xue M (2020) Emergence of a novel coronavirus, severe acute respiratory syndrome coronavirus 2: biology and therapeutic options. J Clin Microbial 58(5):10. https://doi.org/10.1128/JCM.00187-20

16. Bryner J (2020) Cat infected with COVID-19 from owner in Belgium. Live Science. https://www.livescience.com/cat-infectedcovid-19-from-owner.html. Accessed 22 October, 2020.

17. IANS (2020) 4 Tigers, 3 Lions at New York's Bronx Zoo Test Positive for Novel Coronavirus. The Weather Channel. https://weath er.com/en-IN/india/coronavirus/news/2020-04-23-4-tigers-3-lions -new-york-bronx-zoo-test-positive-novel-covid-19. Accessed 15 May 2020. Accessed 22 Oct 2020 
18. Wang Z, Chen X, Lu Y, Chen F, Zhang W (2020) Clinical characteristics and therapeutic procedure for four cases with 2019 novel coronavirus pneumonia receiving combined Chinese and Western medicine treatment. Biosci Trends 14:64

19. Caly L, Druce JD, Catton MG, Jans DA, Wagstaff KM (2020) The FDA-approved drug ivermectin inhibits the replication of SARSCoV-2 in vitro. Antiviral Res 178:104787

20. Brown AJ, Won JJ, Graham RL, Dinnon KH III, Sims AC, Feng JY, Sheahan TP (2019) Broad spectrum antiviral remdesivir inhibits human endemic and zoonotic deltacoronaviruses with a highly divergent RNA dependent RNA polymerase. Antiviral Res 169:104541

21. Wang M, Cao R, Zhang L, Yang X, Liu J, Xu M, Xiao G (2020) Remdesivir and chloroquine effectively inhibit the recently emerged novel coronavirus (2019-nCoV) in vitro. Cell Res 30(3):269-271

22. Chen C, Huang J, Cheng Z, Wu J, Chen S, Zhang Y, Yin P (2020) Favipiravir versus arbidol for COVID-19: a randomized clinical trial. MedRxiv

23. Chu CM, Cheng VCC, Hung IFN, Wong MML, Chan KH, Chan KS, Peiris JSM (2004) Role of lopinavir/ritonavir in the treatment of SARS: initial virological and clinical findings. Thorax 59(3):252-256

24. Hull MW, Montaner JS (2011) Ritonavir-boosted protease inhibitors in HIV therapy. Ann Med 43(5):375-388

25. Teissier E, Zandomeneghi G, Loquet A, Lavillette D, Lavergne JP, Montserret R, Pécheur EI (2011) Mechanism of inhibition of enveloped virus membrane fusion by the antiviral drug arbidol. PLoS ONE 6(1):10. https://doi.org/10.1371/journal.pone.00158 74

26. Liu W, Morse JS, Lalonde T, Xu S (2020) Learning from the past: possible urgent prevention and treatment options for severe acute respiratory infections caused by 2019-nCoV. Chembiochem

27. Liu J, Cao R, Xu M, Wang X, Zhang H, Hu H, Wang M (2020) Hydroxychloroquine, a less toxic derivative of chloroquine, is effective in inhibiting SARS-CoV-2 infection in vitro. Cell Discov $6(1): 1-4$

28. Gao J, Tian Z, Yang X (2020) Breakthrough: chloroquine phosphate has shown apparent efficacy in treatment of COVID-19 associated pneumonia in clinical studies. Biosci Trends 14:72

29. Gautret P, Lagier JC, Parola P, Meddeb L, Mailhe M, Doudier B, Honoré S (2020) Hydroxychloroquine and azithromycin as a treatment of COVID-19: results of an open-label non-randomized clinical trial. Intl J Antimicrob Agents 56:105949

30. Sun ML, Yang JM, Sun YP, Su GH (2020) Inhibitors of RAS might be a good choice for the therapy of COVID-19 pneumonia. Chin J Tubercul Respir Dis 43:E014-E014

31. Kumar V, Jung YS, Liang PH (2013) Anti-SARS coronavirus agents: a patent review (2008-present). Expert Opin Ther Pat 23(10):1337-1348

32. Gordon DE, Jang GM, Bouhaddou M, Xu J, Obernier K, O'meara MJ, Kaake RM (2020) A SARS-CoV-2-human protein-protein interaction map reveals drug targets and potential drug-repurposing. BioRxiv

33. Abbott TR, Dhamdhere G, Liu Y, Lin X, Goudy L, Zeng L, Pande T (2020) Development of CRISPR as an antiviral strategy to combat SARS-CoV-2 and influenza. Cell 181:865

34. Wu C, Liu Y, Yang Y, Zhang P, Zhong W, Wang Y, Zheng M (2020) Analysis of therapeutic targets for SARS-CoV-2 and discovery of potential drugs by computational methods. Acta PharmaceuticaSinica B. 10:76

35. Yuan L, Chen Z, Song S, Wang S, Tian C, Xing G, Zhang L (2015) p53 degradation by a coronavirus papain-like protease suppresses type I interferon signaling. J Biol Chem 290(5):3172-3182
36. Yang H, Xie W, Xue X, Yang K, Ma J, Liang W, Hilgenfeld R (2005) Design of wide-spectrum inhibitors targeting coronavirus main proteases. PLoS Biol 3(10):10. https://doi.org/10.1371/journ al.pbio.0030324

37. Subissi L, Imbert I, Ferron F, Collet A, Coutard B, Decroly E, Canard B (2014) SARS-CoV ORF1b-encoded nonstructural proteins 12-16: replicative enzymes as antiviral targets. Antiviral Res 101:122-130

38. Ivanov KA, Ziebuhr J (2004) Human coronavirus 229E nonstructural protein 13: characterization of duplex-unwinding, nucleoside triphosphatase, and RNA 5'-triphosphatase activities. J Virol 78(14):7833-7838

39. Xia S, Liu Q, Wang Q, Sun Z, Su S, Du L, Jiang S (2014) Middle East respiratory syndrome coronavirus (MERS-CoV) entry inhibitors targeting spike protein. Virus Res 194:200-210

40. Narayanan K, Huang C, Lokugamage K, Kamitani W, Ikegami T, Tseng CTK, Makino S (2008) Severe acute respiratory syndrome coronavirus nsp1 suppresses host gene expression, including that of type I interferon, in infected cells. J Virol 82(9):4471-4479

41. Moore JB, June CH (2020) Cytokine release syndrome in severe COVID-19. Science 368(6490):473-474

42. Abdin SM, Elgendy SM, Alyammahi SK, Alhamad DW, Omar HA (2020) Tackling the cytokine storm in COVID-19, challenges, and hopes. Life Sci 257:118054

43. Rizk JG, Kalantar-Zadeh K, Mehra MR, Lavie CJ, Rizk Y, Forthal DN (2020) Pharmaco-immunomodulatory therapy in COVID-19. Drugs 80:1267

44. Zhao M (2020) Cytokine storm and immunomodulatory therapy in COVID-19: role of chloroquine and anti-IL-6 monoclonal antibodies. Intl J Antimicrobial Agents 55:105982

45. Xu X, Han M, Li T, Sun W, Wang D, Fu B, Zhang X (2020) Effective treatment of severe COVID-19 patients with tocilizumab. Proc Natl Acad Sci 117(20):10970-10975

46. Yeleswaram S, Smith P, Burn T, Covington M, Juvekar A, Li Y, Langmuir P (2020) Inhibition of cytokine signaling by ruxolitinib and implications for COVID-19 treatment. Clin Immunol 218:108517

47. EP News Bureau (2020) Tiziana Life Sciences to expedite development of TZLS-501 for COVID-19. Express Pharma. https:// www.expresspharma.in/latest-updates/tiziana-life-sciences-toexpedite-development-of-tzls-501-for-covid-19/. Accessed 22 Oct 2020.

48. Sharun K, Tiwari R, Dhama J, Dhama K (2020) Dexamethasone to combat cytokine storm in COVID-19: clinical trials and preliminary evidence. Intl J Surg 82:179

49. I-MAB Biopharma (2020) I-mabbiopharma announces development of TJM2 to treat cytokine release syndrome associated with severe and critically-ill patients with coronavirus disease (COVID-19). I-MAB Biopharma. http://www.i-mabbiophar ma.com/en/article-491.aspx. Accessed 22 Oct 2020

50. Randall RE, Goodbourn S (2008) Interferons and viruses: an interplay between induction, signalling, antiviral responses and virus countermeasures. J Gen Virol 89(1):1-47

51. Nodarse-Cuní H, Iznaga-Marín N, Viera-Alvarez D, RodríguezGómez H, Fernández-Fernández H, Blanco-López Y, Cuban Group for the Study of Interferon in Recurrent Respiratory Papillomatosis (2004) Interferon alpha-2b as adjuvant treatment of recurrent respiratory papillomatosis in Cuba: National Programme (1994-1999 report). J Laryngol Otol 118(9):681-687

52. Arabi YM, Alothman A, Balkhy HH, Al-Dawood A, Al Johani S, Al Harbi S, Al-Hameed F (2018) Treatment of Middle East Respiratory Syndrome with a combination of lopinavir-ritonavir and interferon- $\beta 1 b$ (MIRACLE trial): study protocol for a randomized controlled trial. Trials 19(1):81 
53. Sheahan TP, Sims AC, Leist SR, Schäfer A, Won J, Brown AJ, Spahn JE (2020) Comparative therapeutic efficacy of remdesivir and combination lopinavir, ritonavir, and interferon beta against MERS-CoV. Nat Commun 2020:11

54. Finter NB, Chapman S, Dowd P, Johnston JM, Manna V, Sarantis $N$, Tatum PB (1991) The use of interferon- $\alpha$ in virus infections. Drugs 42(5):749-765

55. Kumaki Y, Ennis J, Rahbar R, Turner JD, Wandersee MK, Smith AJ, Barnard DL (2011) Single-dose intranasal administration with mDEF201 (adenovirus vectored mouse interferon-alpha) confers protection from mortality in a lethal SARS-CoV BALB/c mouse model. Antiviral Res 89(1):75-82

56. Falzarano D, De Wit E, Rasmussen AL, Feldmann F, Okumura A, Scott DP, Benecke AG (2013) Treatment with interferon- $\alpha 2 b$ and ribavirin improves outcome in MERS-CoV-infected rhesus macaques. Nat Med 19(10):1313-1317

57. Lokugamage KG, Hage A, Schindewolf C, Rajsbaum R, Menachery VD (2020) SARS-CoV-2 sensitive to type I interferon pretreatment. BioRxiv.

58. Channappanavar R, Fehr AR, Vijay R, Mack M, Zhao J, Meyerholz DK, Perlman S (2016) Dysregulated type I interferon and inflammatory monocyte-macrophage responses cause lethal pneumonia in SARS-CoV-infected mice. Cell Host Microbe 19(2):181-193

59. Elshabrawy HA, Coughlin MM, Baker SC, Prabhakar BS (2012) Human monoclonal antibodies against highly conserved HR1 and HR2 domains of the SARS-CoV spike protein are more broadly neutralizing. PLoS ONE 7(11):50366

60. CytoDyn. Press release (2020) Available on the World Wide Web. https://www.cytodyn.com/newsroom/press-releases/detai 1/405/treatment-with-cytodyns-leronlimab-indicates-significant. Accessed 22 Oct 2020

61. Benucci M, Giannasi G, Cecchini P, Gobbi FL, Damiani A, Grossi V, Manfredi M (2020) COVID-19 pneumonia treated with Sarilumab: a clinical series of eight patients. J Med Virol 92:2368

62. Tian X, Li C, Huang A, Xia S, Lu S, Shi Z, Ying T (2020) Potent binding of 2019 novel coronavirus spike protein by a SARS coronavirus-specific human monoclonal antibody. Emerging Microbes Infect 9(1):382-385

63. Shanmugaraj B, Siriwattananon K, Wangkanont K, Phoolcharoen W (2020) Perspectives on monoclonal antibody therapy as potential therapeutic intervention for Coronavirus disease-19 (COVID19). Asian Pac J Allergy Immunol 38(1):10-18

64. Dhama K, Sharun K, Tiwari R, Dadar M, Malik YS, Singh KP, Chaicumpa W (2020) COVID-19, an emerging coronavirus infection: advances and prospects in designing and developing vaccines, immunotherapeutics, and therapeutics. Human Vacc Immunotherap 16:1232

65. Shen C, Wang Z, Zhao F, Yang Y, Li J, Yuan J, Wei J (2020) Treatment of 5 critically ill patients with COVID-19 with convalescent plasma. JAMA 323(16):1582-1589

66. Duan K, Liu B, Li C, Zhang H, Yu T, Qu J, Peng C (2020) Effectiveness of convalescent plasma therapy in severe COVID-19 patients. Proc Natl Acad Sci 117(17):9490-9496

67. Yang J, Zheng Y, Gou X, Pu K, Chen Z, Guo Q, Zhou Y (2020) Prevalence of comorbidities in the novel Wuhan coronavirus (COVID-19) infection: a systematic review and meta-analysis. Intl J Infect Dis 94:91

68. Ferrario CM, Jessup J, Chappell MC, Averill DB, Brosnihan KB, Tallant EA, Gallagher PE (2005) Effect of angiotensin-converting enzyme inhibition and angiotensin II receptor blockers on cardiac angiotensin-converting enzyme 2. Circulation 111(20):2605-2610

69. Meng J, Xiao G, Zhang J, He X, Ou M, Bi J, Gao H (2020) Reninangiotensin system inhibitors improve the clinical outcomes of COVID-19 patients with hypertension. Emerg Microbes Infect 9(1):757-760
70. Guo T, Fan Y, Chen M, Wu X, Zhang L, He T, Lu Z (2020) Cardiovascular implications of fatal outcomes of patients with coronavirus disease 2019 (COVID-19). JAMA Cardiol 5:811

71. Connors JM, Levy JH (2020) COVID-19 and its implications for thrombosis and anticoagulation. Blood 135(23):2033-2040

72. Clerkin KJ, Fried JA, Raikhelkar J, Sayer G, Griffin JM, Masoumi A, Schwartz A (2020) COVID-19 and cardiovascular disease. Circulation 141(20):1648-1655

73. Volpe M, Tocci G, Battistoni A, Rubattu S (2015) Angiotensin II receptor blocker neprilysin inhibitor (ARNI): new avenues in cardiovascular therapy. High Blood Press Cardiovasc Prev 22(3):241-246

74. Janardhan V, Janardhan V, Kalousek V (2020) COVID-19 as a blood clotting disorder masquerading as a respiratory illness: a cerebrovascular perspective and therapeutic implications for stroke thrombectomy. J Neuroimaging 30(5):555-561

75. Singh AK, Gupta R, Ghosh A, Misra A (2020) Diabetes in COVID-19: prevalence, pathophysiology, prognosis and practical considerations. Diabetes Metab Syndrome 14:303

76. Bloomgarden ZT (2020) Diabetes and COVID-19. J Diabetes 12(4):347-348

77. National Kidney Foundation (2020) Kidney disease and COVID19. National Kidney Foundation. https://www.kidney.org/coron avirus/kidney-disease-covid-19. Accessed 22 Oct 2020.

78. Ajaimy M, Melamed ML (2020) COVID-19 in patients with kidney disease. CJASN 15:1087

79. Wu J, Song S, Cao HC, Li LJ (2020) Liver diseases in COVID19: etiology, treatment and prognosis. World J Gastroenterol 26(19):2286

80. Chen H, Du Q (2020) Potential natural compounds for preventing SARS-CoV-2 (2019-nCoV) infection. Preprints

81. Leung JM, Niikura M, Yang CWT, Sin DD (2020) COVID-19 and COPD. Eur Respir J 56(2):2002108

82. Arabi YM, Mandourah Y, Al-Hameed F, Sindi AA, Almekhlafi GA, Hussein MA, Almotairi A (2018) Corticosteroid therapy for critically ill patients with Middle East respiratory syndrome. Am J Respir Crit Care Med 197(6):757-767

83. Horby P, Mafham M, Linsell L, Bell JL, Staplin N, Emberson JR, Whitehouse A (2020) Effect of hydroxychloroquine in hospitalized patients with COVID-19: preliminary results from a multicentre, randomized, controlled trial. MedRxiv.

84. Simons SO, Hurst JR, Miravitlles M, Franssen FM, Janssen DJ, Papi A, Kerstjens HA (2020) Caring for patients with COPD and COVID-19: a viewpoint to spark discussion. Thorax.

85. Wrapp D, Wang N, Corbett KS, Goldsmith JA, Hsieh CL, Abiona O, McLellan JS (2020) Cryo-EM structure of the 2019-nCoV spike in the prefusion conformation. Science 367(6483):1260-1263

86. Tseng CT, Sbrana E, Iwata-Yoshikawa N, Newman PC, Garron T, Atmar RL, Couch RB (2012) Immunization with SARS coronavirus vaccines leads to pulmonary immunopathology on challenge with the SARS virus. PLOS ONE 7(4):e35421

87. Houser KV, Broadbent AJ, Gretebeck L, Vogel L, Lamirande EW, Sutton T, Subbarao K (2017) Enhanced inflammation in New Zealand white rabbits when MERS-CoV reinfection occurs in the absence of neutralizing antibody. PLoS Pathog 13(8):e1006565

88. Xia S, Liu M, Wang C, Xu W, Lan Q, Feng S, Qin C (2020) Inhibition of SARS-CoV-2 (previously 2019-nCoV) infection by a highly potent pan-coronavirus fusion inhibitor targeting its spike protein that harbors a high capacity to mediate membrane fusion. Cell Res 30(4):343-355

89. Mathieu C, Porotto M, Figueira TN, Horvat B, Moscona A (2018) Fusion inhibitory lipopeptides engineered for prophylaxis of Nipah virus in primates. J Infect Dis 218(2):218-227

90. Jiang S, Bottazzi ME, Du L, Lustigman S, Tseng CTK, Curti E, Hotez PJ (2012) Roadmap to developing a recombinant 
coronavirus S protein receptor-binding domain vaccine for severe acute respiratory syndrome. Expert Rev Vacc 11(12):1405-1413

91. Li E, Yan F, Huang P, Chi H, Xu S, Li G, Yang S (2020) Characterization of the immune response of MERS-CoV vaccine candidates derived from two different vectors in mice. Viruses 12(1): 125

92. Banerjee A, Santra D, Maiti S (2020) Energetics based epitope screening in SARS CoV-2 (COVID 19) spike glycoprotein by Immuno-informatic analysis aiming to a suitable vaccine development. BioRxiv

93. EH News Bureau (2020) Medicago announces production of viable vaccine candidate for COVID-19. Express Healthcare. https:// www.expresshealthcare.in/news/medicago-announces-production -of-viable-vaccine-candidate-for-covid-19/417857/. Accessed 22 Oct 2020

94. Bijlenga G (2005) Proposal for vaccination against SARS coronavirus using avian infectious bronchitis virus strain $\mathrm{H}$ from The Netherlands. J Infect 51(3):263
95. Kim E, Erdos G, Huang S, Kenniston TW, Balmert SC, Carey CD, Korkmaz E (2020) Microneedle array delivered recombinant coronavirus vaccines: immunogenicity and rapid translational development. EBioMedicine 102743

96. CEPI (2020) CEPI to fund three programmes to develop vaccines against the novelcoronavirus, nCoV-2019. CEPI. https://cepi.net/ news_cepi/cepi-to-fund-three-programmes-to-develop-vaccinesagainst-the-novel-coronavirus-ncov-2019/. Accessed 22 Oct 2020

97. The New York Times (2020) Corona Virus Vaccine Tracker. Jonathan Corum, Sui-Lee Wee and Carl Zimmer. https://www. nytimes.com/interactive/2020/science/coronavirus-vaccine-track er.html. Accessed 22 Oct 2020

98. Moderna (2020) Moderna's work on a COVID-19 Vaccine Candidate. Moderna. https://www.modernatx.com/modernas-workpotential-vaccine-against-covid-19. Accessed 22 Oct 2020.

Publisher's Note Springer Nature remains neutral with regard to jurisdictional claims in published maps and institutional affiliations. 